\title{
Observations on the sprainting behaviour of the otter Lutra lutra in the NE Spain
}

\author{
Jordi RUIZ-OLMO and Joaquim GOSÁLBEZ
}

\begin{abstract}
Ruiz-Olmo J. and Gosálbez J. 1997. Observations on the sprainting behaviour of the otter Lutra lutra in the NE Spain. Acta Theriologica 42: 259-270.

In total, 298 transects (each $600 \mathrm{~m}$ long) were surveyed between 1987 and 1995 for otter Lutra lutra (Linnaeus, 1758) signs (spraints, smears and jellies) in nine rivers of NE Spain. Also two stretches of the rivers Noguera Ribagorçana (length $2 \mathrm{~km}$ ) and Noguera Pallaresa (length $2.6 \mathrm{~km}$ ) in the Spanish Pyrenees were surveyed monthly between November 1989 and October 1990 for all otter tracks and signs. In both cases, all stones, rocks, beaches, hollows, caves, walls, shelves, and vegetation in the river and bankside within a $5 \mathrm{~m}$ band from the river edge (each side) were examined. The type of substrate on which findings were made was noted together with, the number of signs at a site. A seasonal pattern was found for the Pyrenean rivers with greatest sign density in winter and spring. In Mediterranean rivers, seasonality was not evident, founding even more signs in summer in some stretches. A total of $547.0 \mathrm{signs} / \mathrm{km}$ were recorded on the river Noguera Ribagorçana during a year of study, of which $9.6 \%$ were smears, $1.0 \%$ jellies and $89.4 \%$ spraints. On the river Noguera Pallaresa 261.5 signs $/ \mathrm{km}$ were noted, of which $9.2 \%$ were smears, $1.1 \%$ jellies and $89.7 \%$ spraints. A variation in sign deposition substrata (earth-beaches, grass, and rocks) and site (banks, middle river islands, caves/cracks, and river-stream confluences) throughout the year was observed. In the Noguera Ribagorçana stretch, periods of greatest sign deposition appear to be related to the presence of cubs. In accordance with the theory of the marking of resource use, a number of the spraints might not be significant, but rather the result of immature cub behaviour.
\end{abstract}

Direcció General del Medi Natural, Gran Vía de les Corts Catalanes, 612, 08007 Barcelona, Spain (JR-O); Departament de Biologia Animal (Vertebrats), Facultat de Biologia, Avda. Diagonal, 645, 08028 - Barcelona, Spain (JG)

Key words: Lutra lutra, marking behaviour, spraints, breeding, Spain

\section{Introduction}

During the 1970s and 1980s the use of otter surveys to study otter distribution was a widespread practice (see Lenton et al. 1980, Mason and Macdonald 1986). The method is based on the marking behaviour of Lutra lutra (Linnaeus, 1758), by the detection of otter signs often deposited in prominent and visible positions. Use of spraints has been revised by several authors (Jefferies 1986, Kruuk et al. 1986, Conroy and French 1987, 1991, Kruuk and Conroy 1987, Macdonald and Mason 1987, Mason and Macdonald 1991). Marking behaviour is, in fact, influenced by a variety of factors (Jenkins and Burrows 1980, Green et al. 1984, 
Ostman et al. 1984). Erlinge (1968), Trowbridge (1983), Durbin (1989), and Kruuk $(1991,1995)$ have shown that otters are able to discriminate between the spraints of different individuals and that the presence of spraints increases the rate of deposition at such sites; but no differences were found in the sprainting rate between sites with own and stranger's spraints (see also Lodé 1996). Most significantly, a seasonal variation in otter marking behaviour has been observed in many areas (Erlinge 1968, Jenkins and Burrows 1980, Mason and Macdonald 1986, Macdonald and Mason 1987, Conroy and French 1987, 1991, Kruuk 1995, Jahrl 1996). In some studies, mainly in Spain and western France, sprainting behaviour appears to be unseasonal (Palomares et al. 1988, Delibes et al. 1991, Lodé 1996).

Moreover, spraints are used mainly to indicate the presence of resources and/or the priority of resource use. Kruuk (1995) undertakes a very interesting analysis of the significance of the sprainting behaviour. This author shows that if otter's social organization is based on the avoidance of other individuals rather than on agression, the scent marks do not need a territorial significance. Sprainting appears to function as a means of communication mainly over periods lasting only a few hours, and is asociated with feeding and other forms of resource utilization.

In addition to spraints, otters also produce smears and jellies (Macdonald and Mason 1987). According to Gorman et al. (1978) the latter are related to the female oestrous cycle, but are produced by both sexes. Trowbridge (1983), Conroy and French (1991), and Carss and Parkinsson (1996), consider that origin of the jellies is gastric (not from anal glands), being produced when otters have not eaten for 18-24 hours; they are not related to the oestrous cycle.

Few data are available on where signs are deposited and the factors affecting their persistence in the environment (Jenkins and Burrows 1980, Mason and Macdonald 1986, Lodé 1996). Knowledge of these behavioural factors is also of great interest in the application of otter surveys. The aim of the present work is to study the factors that influence marking behaviour and to determine the implications they may have for other studies.

\section{Study areas, material and methods}

The study was carried out in NE Spain (Fig. 1), on both Pyrenean (Noguera Ribagorçana, Noguera Pallaresa, Esera, Isábena, Cinca and Segre) and Mediterranean rivers (Montsant, Matarranya and Algars) (see Table 1). Their physiographical charcteristics are well described in Riba et al. (1979), Santanach et al. (1986) and Folch et al. (1984). Pyrenean rivers are more similar to central and northern European rivers; in the Mediterranean rivers little or no water is found in summer.

Two river stretches in the Spanish Pyrenees (55 km away from each other) were chosen for more detailed observations. Selection of both stretches was based on a well-documented presence of otters, ease of sign detection and the contrast provided by two very different areas:

(1) The river Noguera Ribagorçana stretch (length $2 \mathrm{~km}$ ). Altitude between 505 and $530 \mathrm{~m}$. The width ranges from 5.5 to $11 \mathrm{~m}$, with a flow of $1-3 \mathrm{~m}^{3} / \mathrm{s}$. Limited vegetation cover composed mainly of Salix eleagnus, Populus nigra, and Typha latifolia. River banks with abundant mud (which helped significantly to detect tracks), earth, stones, and large blocks of rocks. Productive waters with abundant fish (Ruiz-Olmo 1995a) and a high otter density (> 0.7-0.9 otters/km; Ruiz-Olmo 1995b). 


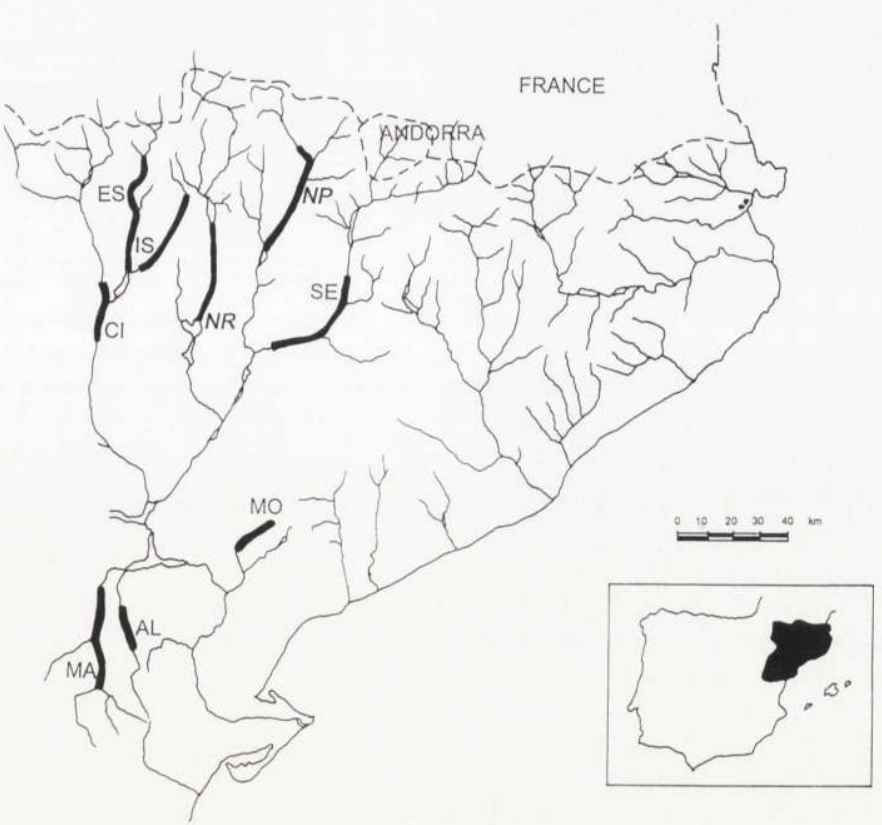

Fig. 1. River stretches under study: ES - Esera, IS - Isábena, CI - Cinca, NR - Noguera Ribagorçana, NP - Noguera Pallaresa, SE - Segre, MO - Montsant, MA - Matarranya, and AL - Algars.

(2) The river Noguera Pallaresa stretch (length $2.6 \mathrm{~km}$ ). Altitude between 630 and $810 \mathrm{~m}$. Average width $21-23 \mathrm{~m}$, with a flow of $15-30 \mathrm{~m}^{3} / \mathrm{s}$. Vegetation cover very limited and composed largely of isolated young trees (Populus nigra, Alnus glutinosa and Fraxinus spp.). River banks and bed consisting almost exclusively of large rocks (either natural or the result of road widening a few years before). Slightly oligotrophic waters, with scarce fish production (Ruiz-Olmo 1995a) and low otter density (Ruiz-Olmo 1995b).

Between 1987 and 1995, 298 transects (each $600 \mathrm{~m}$ long) were surveyed for otter signs. The two Pyrenean river streches were surveyed monthly between November 1989 and October 1990. In all cases, riverbanks and islands were surveyed $(0.7-1 \mathrm{~km} / \mathrm{h}$ ) for all tracks, spraints, smears, and jellies (see definitions in Macdonald and Mason 1987). All stones, rocks, beaches, hollows, caves, walls, shelves, and vegetation in the river and bankside within a $5 \mathrm{~m}$ band from the river edge (each side) were examined. For spraints, smears and jellies, the type of substrate, on which findings were made, was noted together with, where applicable, the number of signs at a site (point with one or more signs separated by a distance of at least $1 \mathrm{~m}$ ). It could affect the otter's spraint behaviour (but in the study area it happens often by the effect of variations in the water level). However, we removed the otter spraints, smears and jellies every month (starting one month before the study begin), following the same methods; monthly difference can not be due to the fact of removing it.

Otter cub footprints were recorded in the Noguera Ribagorçana and Noguera Pallaresa stretches. They were easily recognizable due to smaller dimensions (Macdonald and Mason 1987, Sidorovich 1992, Ruiz-Olmo 1994).

Although most authors present data as the absolute number of spraints and jellies, this can create difficulties when studies carried out over different distances are to be compared. In our study area spraints remain for longer periods than in central and northern Europe, beacuse dry weather (our 
unpublished data) and because the main part of signs are out of the reach of maximum water level (caves, big rocks). Also, the periodicity of the study can be different. The following sprainting index (SI) was therefore defined to study the sprainting behaviour of otters in both stretches of rivers Noguera Ribagorçana and Noguera Pallaresa (monthly surveyed):

$$
\mathrm{SI}=\mathrm{NS} \times 100 / \mathrm{D} \times \mathrm{d}
$$

where NS is the number of signs (sprains and smears), D the number of days since the last visit and $\mathrm{d}$ the distance covered (in $\mathrm{km}$ ). This index was also applied to the number of latrines or sites (LSI) on both stretches.

As is common in other published studies, in the 600 -m-long transects we use the total number of signs detected per surveyed length (signs $/ \mathrm{km}$ ). To study the effect of washing caused by rises in river level, the river Noguera Ribagorçana was visited during the months when floods could be anticipated prior to monthly sampling, and the position of spraints noted (without being removed). The study of substrate selection, deposition site, effect of water level rise, and the presence of cub footprints could only be carried out on the $2 \mathrm{~km}$ stretch of the river Noguera Ribagorçana due to the insufficient number of signs detected on the river Noguera Pallaresa stretch.

Finnally, we use the data from the otter surveys of 1984-1985 and 1989-1990 in northeastern Spain, to know the number of signs in sprainting sites, following the method described by Mason and Macdonald (1986) and Delibes (1990).

\section{Results}

\section{Total annual number of signs}

A total of 1094 signs were found on the river Noguera Ribagorçana stretch, of which $9.6 \%$ were smears, $1.0 \%$ jellies and $89.4 \%$ spraints. This suggests an average of 1.5 signs $/ \mathrm{km}$ per day and an annual density of 547 otter signs $/ \mathrm{km}$ : 489 spraints $/ \mathrm{km}, 52.5$ smears $/ \mathrm{km}$ and 5.5 jellies $/ \mathrm{km}$ per year.

On the river Noguera Pallaresa stretch 523 signs were recorded of which $9.2 \%$ were smears, $1.1 \%$ jellies and $89.7 \%$ spraints. The average density was 0.55 signs $/ \mathrm{km}$ per day with an annual density of $201.1 \mathrm{signs} / \mathrm{km}$ : 180.4 spraints $/ \mathrm{km}$ per year, $18.5 \mathrm{smears} / \mathrm{km}$ per year and 2.3 jellies $/ \mathrm{km}$ per year. No significant difference in the proportion of smears, jellies and spraints on the two river stretches was found $\left(\chi^{2}=0.137, \mathrm{df}=2, p=0.934\right)$. Despite the painstaking nature of the search, the effect of water level rises in March and April together with dense vegetation cover in some areas suggests that some signs would not be detected, implying that actual sign density may be slightly higher.

On the Noguera Ribagorçana stretch a strong correlation exists between the number of spraints and smears found each month $\left(r_{\mathrm{P}}=0.75, p=0.005\right)$. The small number of smears found on the Noguera Pallaresa stretch made analysis of this type impossible. Spraints, smears and jellies were therefore considered together (= signs).

Jellies were found on both stretches in November (4.5 and $15.6 \%$ of the signs respectively, $n=66$ and 32 ) and December (5.4 and 2.9\% of the signs, $n=129$ and 34 ) although one was also found in February ( $0.5 \%$ of the signs, $n=217$ ) on the Noguera Ribagorçana stretch. 


\section{Temporal changes of the number of signs}

We found seasonal significant differences in the marking behaviour of otters in the studied Pyrenean rivers (Table 1). Normally, density of signs is higher in winter and/or spring, and lower in summer. In the Mediterranean rivers seasonality is not evident, finding even more signs in summer than in other seasons. The maximun density in a stretch was: 657 signs $/ \mathrm{km}$ in Noguera Ribagorçana, 91.4 in Noguera Pallaresa, 25.0 in the Esera, 94.3 in the Isábena, 784.0 in the Cinca, 150.0 in the Segre, 70.0 in the Montsant, 290.3 in the Matarranya, and 70.0 in the Algars.

Also, a seasonal pattern was found for SI on the Noguera Ribagorçana stretch $\left(\chi^{2}=311.50, \mathrm{df}=11, p=0.0001\right)$, with greatest spraint abundance in January and February (Fig. 2a). The number of signs was much lower in summer and autumn. SI was at a minimum in July (34.5). In the Noguera Pallaresa stretch variations

Table 1. Monthly variation of the average number $(\bar{x})$ of otter signs (spraints, smears and jelies) in 600 -m-long transects in northeastern Spain. Data in signs $/ \mathrm{km}$. SE - standard error, $n$ - sample size.

\begin{tabular}{|c|c|c|c|c|c|c|c|c|c|c|c|c|c|c|}
\hline \multirow{2}{*}{ River } & \multirow{2}{*}{$\begin{array}{l}\text { Altitude } \\
(\mathrm{m})\end{array}$} & \multirow{2}{*}{ Type } & \multicolumn{3}{|c|}{ Spring } & \multicolumn{3}{|c|}{ Summer } & \multicolumn{3}{|c|}{ Autumn } & \multicolumn{3}{|c|}{ Winter } \\
\hline & & & $\bar{x}$ & SE & $n$ & $\bar{x}$ & $\mathrm{SE}$ & $n$ & $\bar{x}$ & $\mathrm{SE}$ & $n$ & $\bar{x}$ & $\mathrm{SE}$ & $n$ \\
\hline Noguera & $500-750$ & Pyrenean & 112.0 & 3.25 & 6 & 23.9 & 0.79 & 36 & 50.1 & 1.46 & 17 & 222.4 & 4.40 & 13 \\
\hline Ribagorçana & & & & & & & & & & & & & & \\
\hline $\begin{array}{l}\text { Noguera } \\
\text { Pallaresa }\end{array}$ & $490-1000$ & Pyrenean & 16.8 & 1.13 & 7 & 14.0 & 0.43 & 93 & 12.9 & 0.62 & 28 & 21.1 & 1.02 & 6 \\
\hline Esera & $500-1000$ & Pyrenean & - & - & - & 5.8 & 0.56 & 16 & 12.0 & 0.62 & 20 & 10.6 & 1.99 & 2 \\
\hline Isábena & $500-850$ & Pyrenean & - & - & - & 11.8 & 0.85 & 19 & 39.6 & 2.33 & 6 & 45.0 & - & 1 \\
\hline Cinca & $300-400$ & Pyrenean & 92.2 & 3.91 & 6 & 59.8 & 2.48 & 14 & 42.6 & 2.59 & 12 & 374.7 & 11.13 & 3 \\
\hline Segre & $275-430$ & Pyrenean & 72.0 & 3.83 & 4 & 2.2 & 0.92 & 3 & - & - & - & 4.2 & 0.99 & 6 \\
\hline Montsant & $300-550$ & Mediterranean & 12.3 & 1.19 & 10 & 13.7 & 1.07 & 13 & - & - & - & 22.5 & 2.83 & 4 \\
\hline Matarranya & $350-600$ & Mediterranean & - & - & - & 100.5 & 3.25 & 34 & 32.4 & 1.96 & 10 & - & - & - \\
\hline Algars & $400-510$ & Mediterranean & 10.0 & 0.92 & 6 & 16.3 & 0.87 & 11 & 15.1 & 0.73 & 6 & 12.6 & 2.30 & 6 \\
\hline
\end{tabular}
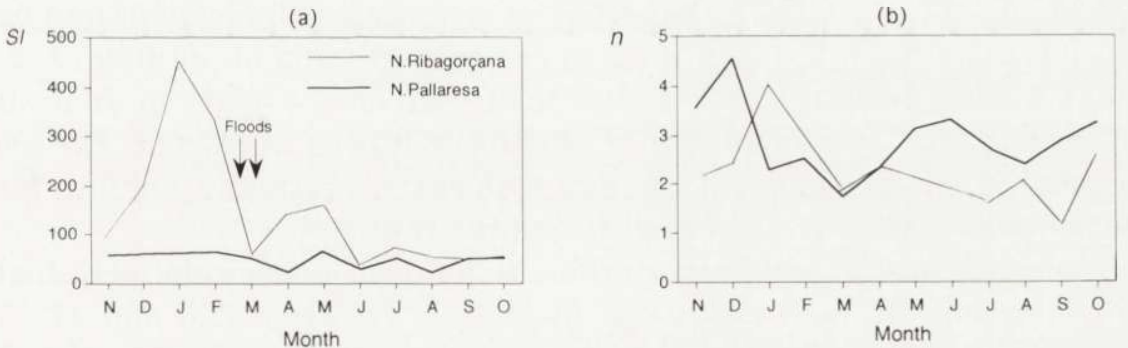

Fig. 2. Monthly variation of (a) the sprainting index (SI) and (b) mean number of signs per site $(n)$ on the two stretches of the rivers Noguera Ribagorçana and Noguera Pallaresa. 
were not significant $\left(\chi^{2}=17.18, \mathrm{df}=11, p=0.103\right)$, even though more spraints were found in winter than in summer. An almost identical tendency was observed for LSI in both Pyrenean stretches. It is worth noting that the number of sprainting sites is highly correlated to the number of signs on both stertches: Noguera Ribagorçana $\left(r_{\mathrm{P}}=0.935, p=0.001\right)$ and Noguera Pallaresa $\left(r_{\mathrm{P}}=0.84, p=0.001\right)$.

\section{Number of signs at the latrines or sites}

Considering all the data, we found differences in the number of spraints per site, reaching a maximum of 282 (one time). Some other big latrines were found (230, 101 and 79 on one occasion each), always associated to caves and dens. During the otter survey of 1984-1985, carried out in the NE Iberian Peninsula, $90.8 \%$ of signs $(n=130)$ and $94.6 \%$ of sprainting sites $(n=61)$ had 5 or less signs per site (maximum 12). During the 1989-1990 survey, 95.3\% of signs ( $n=145$ ) and $98.6 \%$ of sites $(n=72)$ were in sprainting sites with 6 or less signs per site (maximum 7). Average sign number per site were 2.13 and 2.01, respectively.

On the Noguera Ribagorçana stretch the mean number of signs per site across the studied year (considering that the signs were removed monthly) was 2.58 (SE $=0.07$, range $1-16, n=418$ sites). On the Noguera Pallaresa stretch this value was 2.83 ( $\mathrm{SE}=0.16$, range $1-15, n=112$ sites). A seasonal variation in the mean number of signs per site was observed in both rivers (Fig. 2b). Differences in monthly means were statistically significant between some months for both stretches (Mann Whitney $U$-test). On the Noguera Ribagorçana stretch the number of signs per site peaked in January (4.03 signs/site, $\mathrm{SE}=0.22$, range $1-16, n=$ 70 sites) with the minimum occurring in September (1.18 signs/site, $\mathrm{SE}=0.09$, range $1-3, n=24$ sites). On the Noguera Palleresa stretch a peak occurred in December (4.57 signs/site, $\mathrm{SE}=0.48$, range $1-13, n=17$ sites) and the minimum in May (1.73 signs/site, $\mathrm{SE}=0.30$, range $1-10, n=11$ sites,).

\section{Substrata selection for sign deposition}

For some substrata a variation in sign deposition throughout the year was observed in the stretch of the river Noguera Ribagorçana (Fig. 3): grass $\left(\chi^{2}=\right.$ $66.34, \mathrm{df}=11, p=0.0001)$, rocks $\left(\chi^{2}=54.96, \mathrm{df}=11, p=0.0001\right)$, and earth-beaches $\left(\chi^{2}=19.25, \mathrm{df}=11, p=0.057\right)$. Deposition of signs on earth (or mud) and beaches (Fig. 3c) increased from the end of summer and beginning of autumn $(0-2.6 \%$ of the signs), peaked in May (16.2\%), and then decreased rapidly in June (0\%). A bimodal distribution was found with a second small peak in August. The monthly distribution of signs deposited on grass shows a markedly similar bimodal distribution with peaks in April and September (Fig. 3b).

Rock marking presented a very different pattern, being relatively high and constant between July and February (fluctuating between 27.3 and $47.4 \%$ ) but falling sharply to 0\% in March, and remaining below 10\% between April and June (inclusive) (Fig. 3b). The low values in March and April can be partly explained by the rise in water levels affecting the persistence of signs. 

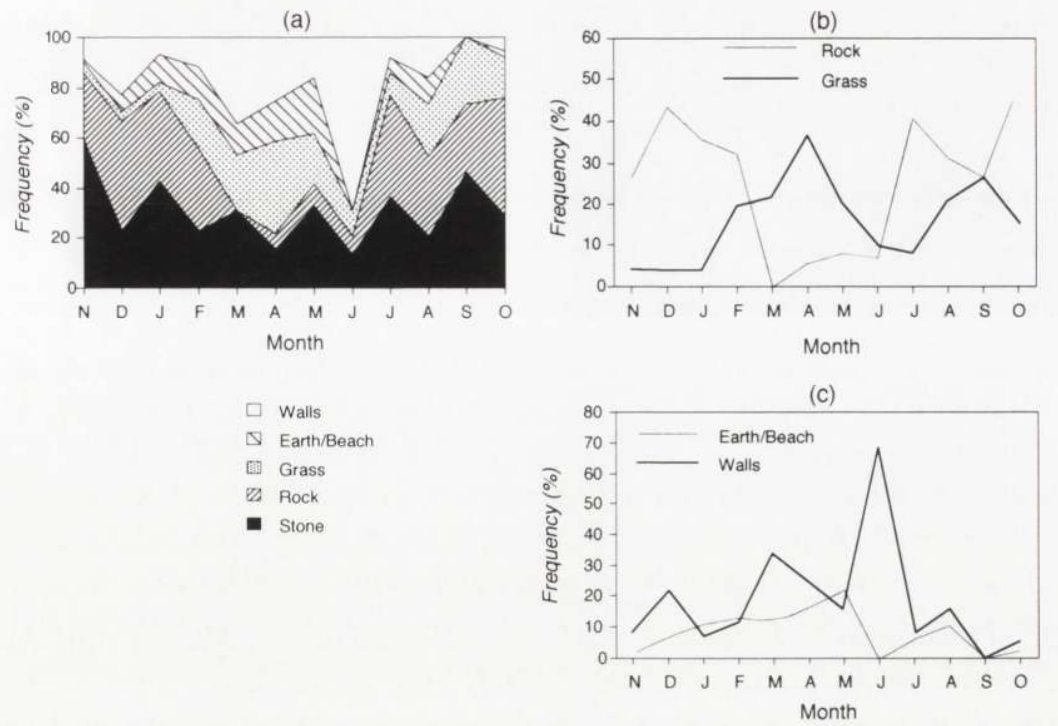

Fig. 3. Substrate selection for spraint deposition in the river Noguera Ribagorçana: (a) overall total, (b) rocks and grass, and (c) walls and earth-beaches. $100 \%$ is total number of spraints deposited during a given month.

For deposition in hollows and wall cracks no marked variation was observed, with the exception of June, when $69 \%$ of total signs were found on this substrate (Fig. 3c). Given that this parameter is not influenced by water level fluctuations, it would seem to reflect that the few signs deposited in this period in this stretch $(\mathrm{SI}=34.5)$ were situated particularly in hollows and cracks away from the river, and not in the usual areas.

\section{Site selection for sign deposition}

The monthly fluctuations in the use of different types of deposition site (Fig. 4) showed significant differences in the river Noguera Ribagorçana stretch: banks $\left(\chi^{2}=211.67, \mathrm{df}=11, p=0.0001\right)$, centre (ie river islands $)\left(\chi^{2}=119.02, \mathrm{df}=11\right.$, $p=0.0001)$, caves/rock fissures $\left(\chi^{2}=31.26, \mathrm{df}=11, p=0.001\right)$, and confluence of rivers $\left(\chi^{2}=20.31, \mathrm{df}=11, p=0.041\right)$.

Sign deposition on the river banks was mostly constant throughout the year (40-65\%), with the exception of June and July, when a sharp decline was observed, particularly in June $(6.9 \%)$. In contrast, sign deposition on river islands was greatest in summer (July-August) and at a minimum in spring (March-April), although in the latter case the rise in water level may partly explain these low values. 


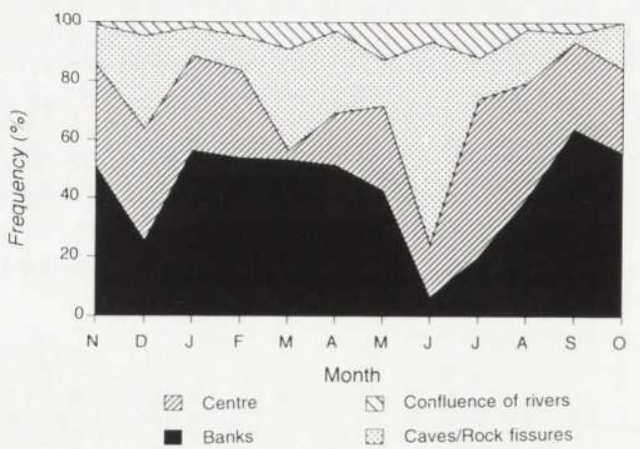

Effect of water level rises on spraint persistence
Fig. 4. Site selection for spraint deposition in the river Noguera Ribagorçana. $100 \%$ is total number of spraints deposited during a given month.

The most prounounced rises in river level occurred in March and April 1990 on the Noguera Ribagorana stretch, when the water level rose to $0.75-1 \mathrm{~m}$. Considering only those signs found near the river bank $(<2 \mathrm{~m})$ and on islands (most affected by river rises), a density of 9.0 signs $/ \mathrm{km}$ was found in March and 24.5 in April. This compares to February and May when 95.0 and 45.5 signs $/ \mathrm{km}$ were found, respectively.

To evaluate the effect of washing on signs (to which the effect of a whole or partial covering of mud, making signs equally undetectable, should be added) several traditional marking sites on the Noguera Ribagorçana stretch were prospected in March and April (before the foreseeable water rises), and the number of spraints recorded. In March, seven spraints were below the maximum water level attained, of which only one survived the floods ( $14.3 \%$ persistence). In April, 19 of the previously noted spraints were covered by water, with only three found after the flood (15.8\% persistence).

\section{Tracks and spraints}

A total of 560 otter tracks were found on the Noguera Ribagorçana stretch between November 1989 and October 1990, but very few on the Noguera Pallaresa. The abundance of mud everywhere along the river on the first river and the almost complete lack of mud on the second river explain this difference. No significant difference was found between the number of spraints and tracks found monthly on the stretch of the river Noguera Ribagorçana $\left(r_{\mathrm{P}}=0.011, n=12\right)$ : we did not find more spraints where more tracks were present.

No otter cubs were detected on the Noguera Pallaresa stretch from footprints. We did not find other evidences of breeding or presence of cubs in this section, as was common in previous years. On the Noguera Ribagorçana stretch, however, a total of 21 otter cub tracks were detected: 12 in November 1989, 3 in December 1989 and 6 in October 1990. If these data are compared to Figs 2 and 3, it will be observed that periods of greater sign deposition do not correspond exactly to 
the presence of small cubs (3-4 month old). However, growth of the cubs (later not distinguishable from the adults by their footprints), their departure from holts, increased activity and subsequent dispersion, could be related in part to the increase in marking rate. In fact, an increase is noted in the presence of spraints just after the detection of the cubs in both years.

\section{Discussion}

The results presented in this paper suggest that the rate of spraint deposition does not appear to be related exclusively to otter abundance (estimated from footprints in the mud). Our results show monthly fluctuations in sign abundance and in the deposition site and substrata used throughout the year, in addition to a variation between localities. In agreement with most existing studies in northern and central Europe (Mason and Macdonald 1986, Macdonald and Mason 1987, Conroy and French 1987, 1991, Jahrl 1996), a seasonal pattern of increased marking activity in winter, falling to a low level in summer, has been observed in the Pyrenean rivers of the NE Iberian Peninsula. On the Shetland Islands, Kruuk (1991, 1995) similarly found that the rate of spraint deposition varied throughout the year, being markedly lower in summer. Some locations deviate from the most frequent pattern (Watson 1978, Jenkins and Burrows 1980, Lodé 1996). Sign abundance may also be influenced by the amount and kind of food ingested and would therefore be affected by fluctuating nutritional requirements throughout the year, normally higher in winter. This would not, however, explain the sharp fluctuations in deposition rate observed on the Shetland Islands. Also, otters can spraint directly in water (Kruuk 1995).

This model does not, however, apply to the southern Mediterranean freshwaters, where such prounounced seasonal fluctuations are not usually observed, variation being more dependent on the area and the year, and showing even summer peaks (López-Nieves and Hernando 1984, Palomares et al. 1988, Delibes et al. 1991, this study). These variations, then, do not correspond to a fixed pattern for the species and must therefore be related to other features, possibly variations in environmental conditions, biology or behaviour.

Different causes for these seasonal fluctuations have been suggested: territorial behavioural variations (Green et al. 1984), reproductive and sexual behaviour (Ostman et al. 1984, Green et al. 1984), presence of cubs and their dispersion (Green et al. 1984, Macdonald and Mason 1987, Conroy and French 1987, 1991, Jahrl 1996), communication (Macdonald and Mason 1987, Durbin 1989), and indication of resource use and shelter (Kruuk 1991, 1995).

During the present study the cubs detected on the river Noguera-Ribagorçana in 1990 were born in June-July (lower spraint density in June-October) and were conceived around April-May, which does not coincide with the peak of sign deposition. Heggberget (1993) suggests that even though otter births may show seasonal variations in certain areas, the cycle is actually polyoestrous and that 
although individuals may be active for most of the year, seasonal fluctuations in reproduction depend more on the availability of food than on endogen/oestrous cycles. Thus, the males should mark in a similar proportion throughout the year, which is not the case.

Kruuk (1995) indicates that spraints are largely used to prevent competition, advertising the use of a resource (food, shelter, freshwater, etc.). For this reason, sprainting should occur particularly at times when resources are scarce (winter in northern and central Europe). In Spanish Mediterranean habitats, during dry summers, food shortages occurs at this moment, after fish mortalities (Ruiz-Olmo 1995a). But in wet years, food is more available in summer, when higher rates of sprainting are observed in some stretches.

But while agreeing with Kruuk's (1995) theory of the marking of resource use, a part of the deposited spraints cannot be explained solely from this point of view. It has been suggested that fluctuations in marking behaviour are closely related to reproduction and/or independence of the cubs. Females might cease to mark during the perinatal period and both females and cubs avoid sprainting in the first weeks after birth (Ostman et al. 1984, Green et al. 1984, Conroy and French 1991), a tendency which is reversed when the cubs begin their movements (Mason and Macdonald 1986, Macdonald and Mason 1987, Conroy and French 1987, 1991, Jahrl 1996). This behaviour suggests that areas with clear seasonal variations in reproduction would be even more likely to have seasonal fluctuations in marking patterns. In our study area, in early summer, coinciding with reproduction, the proportion of 'hidden' signs is greater than during the rest of the year, given that the number and proportion of signs deposited in caves and fissures of the river banks, rocks and walls, and islands increases. Whereas those situated on river banks decrease. The observed increase in sign density in this area occurs after the detection of small cubs (they go outside the den at age of 3-4 months; see Mason and Macdonald 1986), perhaps suggesting that a part of the increased spraint activity is due to the presence of cubs outside the den, together with a resumed marking activity of the females. Ruiz-Olmo (1995a) found a relationship between the presence of big latrines (25 spraints) and the presence of cub's tracks. The timing of peak values observed on the Noguera Ribagorçana stretch (from January to March), would further reinforce this theory, corresponding to an age of 4-7 months in the cubs. In the Pyrenees seasonal reproduction predominates (Ruiz-Olmo 1994). Cubs are born between May and September, which would largely coincide with the observed seasonal marking pattern. Thus the progressive increase in signs detected during autumn and winter would coincide with the cubs movements and independence. The sharp decrease in summer marking activity would also be determined by reproductive behaviour (pregnant females and cubs in holts). During the period of study, food and holt availabilty in the Noguera Ribagorçana was always high, even in winter (J. Ruiz-Olmo and J. Gosálbez, unpubl.). In the river Noguera Pallaresa, where no evidence of cubs was found, monthly differences in sprainting were not significant. 
According to Conroy and French (1991) and Carss and Parkinson (1996), the production of jellies occurs when otters do not eat for periods of more than one day, which would be useful for detecting periods of food shortage. For this reason jellies are usually more frequent in winter (Macdonald and Mason 1987, Conroy and French 1991, this study). In the Shetland Islands and Wales (Macdonald and Mason 1987), however, jellies are found throughout the year, whereas production in our study area was limited to winter. Differences in relative proportions are also recorded; in the North of Spain jellies represent normally less than $1 \%$ of the total signs (= spraints, smears and jellies), while in Wales the monthly values frequently range between 5 and $10 \%$. This physiological feature could be used to detect periods of severity (food shortages) or to compare food availability in different populations.

The results presented here demonstrate the importance of carrying out the 'Otter Surveys' at the same time of year or under similar conditions, if results are to be comparable (Conroy and French 1991). Moreover, if the density of signs is to be used as an index of abundance, seasonal sprainting patterns in each area must first be determined (see Kruuk et al. 1986, Kruuk and Conroy 1987, Conroy and French 1987, 1989, Kruuk 1995).

Acknowledgments: We would like to thank X. Parellada, J. M. López-Martín, S. Palazón, and S, Ruiz-Romero for their help and companionship on various field surveys. K. Bush kindly corrected our English. Figures were made by J. M. López-Martín.

\section{References}

Carss D. N. and Parkinson S. G. 1996. Errors associated with otter Lutra lutra faecal analysis. I. Assessing general diet from spraints. Journal of Zoology, London 238: 301-317.

Conroy J. W. H. and French D. D. 1987. The use of spraints to monitor populations of otters (Lutra lutra L.). Symposia of the Zoological Society of London 58: 247-262.

Conroy J. W. H. and French D. D. 1991. Seasonal patterns in the sprainting behaviour of otters (Lutra lutra L.) in Shetland. (In: Proceedings of 5th International Otter Colloquium, Hankensbüttel 1989. C. Reuther and R. Röchert, eds]. Habitat 6: 159-166.

Delibes M. 1990. La nutria (Lutra lutra) en España. Serie Tècnica. ICONA, Madrid: 1-198.

Delibes M., Macdonald S. M. and Mason C. F. 1991. Seasonal marking, habitat and organochlorine contamination in otters (Lutra lutra): a comparison between catchments in Andalucia and Wales. Mammalia 55: 567-578.

Durbin L. 1989. Some responses of otters Lutra lutra to strange and familiar spraints. Lutra 32: $132-138$.

Erlinge S. 1968. Territoriality of the Otter Lutra lutra L. Oikos 19: 81-98.

Folch R. (ed) 1984. Vegetació. [In: Història Natural dels Països Catalans, 7]. Enciclopedia Catalana, Barcelona: 1-442.

Gorman L. G., Jenkins D. and Haprper R. J. 1978. The anal scent sacs of the otter (Lutra lutra). Journal of Zoology, London 186: 463-474.

Greeen J., Green R. and Jefferies D. J. 1984. A radio-tracking survey of otters Lutra lutra on a Perthshire river system. Lutra 27: 85-145.

Heggberget T. M. 1993. Reproductive strategy and feeding ecology of the Eurasian Otter Lutra lutra. Dr Sc thesis. University of Trondheim, Trondheim: 1-24. 
Jahrl J. 1996. Marking behaviour of Lutra lutra in Austria. [In: Proceedings of 6th International Otter Colloquium, Pietermaritzburg (South Africa) 1993. C. Reuther and D. Rowe-Rowe, eds]. Habitat 11: 131-134.

Jefferies D. J. 1986. The value of otter (Lutra lutra) surveying using spraints: an analysis of its success and problems in Britain. Journal of Otter Trust 1985: 25-32.

Jenkins D. and Burrows D. 1980. Ecology of otters in northern Scotland. III. The use of faeces as indicators of otter (Lutra lutra) density and distribution. Journal of Animal Ecology 49: 755-774.

Kruuk H. 1991. Scent marking by otters (Lutra lutra): signaling the use of resurces. Behavioural Ecology 3: 133-140.

Kruuk H. 1995. Wild otters. Predation and populations. Oxford University Press, Oxford: 1-304.

Kruuk H. and Conroy J. W. H. 1987. Surveying otters Lutra lutra populations: A discussion of problems with spraints. Biological Conservation 41: 179-183.

Kruuk H., Conroy J. W. H., Glimmrveen U. and Ouwererk E. J. 1986. The use of spraints to survey populations of otters Lutra lutra. Biological Conservation 35: 187-194.

Lenton E. J., Chanin P. R. F. and Jefferies D. J. 1980. Otter survey of England 1977-79. Nature Conservance Council, London: 1-75.

Lodé T. 1996. Variations de la fréquence de marquage de Lutra lutradans l'ouest de France. Cahiers d'Ethologie 15(2-3-4): 245-250.

López-Nieves P. and Hernando J. A. 1984. Food habits of the otter (Lutra lutra L., 1758) in central Sierra Morena (Córdoba, Spain). Acta Theriologica 29: 383-401.

Macdonald S. M. and Mason C. F. 1987. Seasonal marking in an otter population. Acta Theriologica 32: 449-462.

Mason C. F. and Macdonald S. M. 1986. Otters. Ecology and conservation. Cambridge University Press, Cambridge: 1-236.

Mason C. F. and Macdonald S. M. 1991. Assessment of otter (Lutra lutra) survey methods using spraints. [In: Proceedings of 5th International Otter Colloquium, Hankensbüttel 1989. C. Reuther and R. Röchert, eds]. Habitat 6: 167-170.

Ostman J., Hillegaart V. and Sandegreen F. 1984. Behavioural changes in captive female otters (Lutra lutra) around parturition. Otters 1: 58-63.

Palomares F., Delibes M., Adrián M. I., Rodriguez A. and Moreno S. 1988. Variación estacional de la frecuencia de marcaje con heces por Lutra lutra en el bajo Guadalquivir, Suroeste de España. Acta Coloquio Luso-Espanhol de Bacías Hidrologicas e Recursos Zoologicos: 313-318.

Riba O., de Bols O., Panareda J. M., Nuet J. and Gosálbez J. 1979. Geografía física dels Pasos Catalans. Ketres Ed., Barcelona: 1-226.

Ruiz-Olmo J. 1994. Reproducción y observación de grupos de nutria (Lutra lutra L.) en el norte de España. Miscellània Zoologica 17: 225-229.

Ruiz-Olmo J. 1995a. Estudio bionómico de la nutria (Lutra lutra L., 1758) en aguas continentales de la Península Ibérica. Ph D thesis, University of Barcelona, Barcelona: 1-321.

Ruiz-Olmo J. 1995b. Visual otter census: a new method. [In: Proceedings of 6 th International Otter Colloquium, Pietermarizbourg (South Africa), September 1993. C. Reuther and D. Rowe-Rowe, eds]. Habitat 11: 125-130.

Santanach P. 1986. Geología (I). [In: Història Natural dels Països Catalans, 1]. Enciclopdia Catalana, Barcelona: 1-439.

Sidorovich V. E. 1992. Numbers of otters and approach to population estimation in Byelorussia. IUCN Otter Specialist Group Bulletin 7: 13-16.

Trowbridge B. J. 1983. Olfactory communication in the European otter (Lutra lutra). Ph D thesis. University of Aberdeen, Aberdeen: 1-201.

Watson H. 1978. Coastal otters in Shetland. Chapman \& Hall, London \& New York: 1-80.

Received 11 December 1995, revised 8 October 1996, accepted 2 November 1996. 